\title{
International Commission on Stratigraphy (ICS)
}

\author{
http://www.stratigraphy.org
}

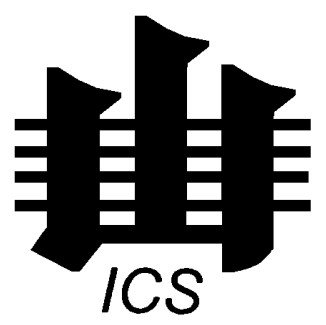

\section{Objectives}

The International Commission on Stratigraphy (ICS) of IUGS is a body of expert stratigraphers founded for the purpose of promoting and coordinating long-term international cooperation and of establishing standards in stratigraphy. The ICS has five main objectives:

\section{Standard Geologic Time Scale}

Establishment and publication of a standardized global stratigraphic time scale. The basal boundary of each global stage in the international geologic scale is standardized at a point in a single reference section within an interval exhibiting continuous sedimentation. This precise reference point for each boundary is known as the Global Stratotype Section and Point (GSSP), and represents the point in time when that part of the rock succession and associated geologic stage began. For example, the base of the Devonian System (and base of Lochkovian Stage) is fixed at a level in Bed \#20 of the Klonk Section, NE of the village of Suchomasty, Czech Republic, and coincides with the first occurrence of the graptolite Monograptus uniformis. The global chronostratigraphic scale is ultimately defined by a sequence of GSSPs that delimit and stabilize the geologic time divisions. Geo-history finally has a universal language, and therefore the underpinnings of a true "Standard" Geologic Time Scale. As of 2004 , approximately $2 / 3 \mathrm{rds}$ of the international geologic stages are standardized by GSSPs at their bases (see table in Episodes v. 27, n. 2), and this standardization will be completed by 2008 .

However, Earth history is a continuum of biologic, environmental and other events between these global GSSP boundaries. The complete Geologic Time Scale consists of the relative succession and approximate relationship of all widespread events and trends, such as evolution and extinction of major biologic species, significant climatic oscillations, geomagnetic reversals, records of carbon cycling (e.g., carbon-13 isotope ratios), and global sea-level variations. The current geologic time scale has been calibrated by suites of radiometric ages and by counting elapsed orbital (Milankovitch) climate cycles in the rock record. The five-year project of "A Geologic Time Scale 2004" by members of ICS documents the international scale and its ages (Gradstein, Ogg, Smith et al., published by Cambridge University Press, August 2004, 500 pages).

\section{Stratigraphic Information and Databases}

Compilation and maintenance of a stratigraphic data base center for the global earth sciences. The ICS website (www.stratigraphy.org) contains a wealth of information, such as summaries and diagrams of ratified and potential GSSPs, age estimates for stage boundaries, time scale graphics for public downloading, and other basic information. ICS has partnered with the CHRONOS effort sponsored by the U.S. National Science Foundation to link international stratigraphic databases on all aspects of chronostratigraphy (paleontology, isotopes, cycles, magnetics, etc.) and to provide analytical and visualization tools (www.chronos.org; see also summary at www.eas.purdue.edu/chronos). Current ICS database projects include documentation of major biostratigraphic zonations that are widely used in each region and databases of the suites of fossils, sealevel excursions, isotopes and other information for major "type sec- tion" reference standards for each regional scale. The ICS is encouraging a global effort to transform the localized knowledge acquired by regional geological surveys and by generations of "Earth historians" into a valuable public network to decipher the past.

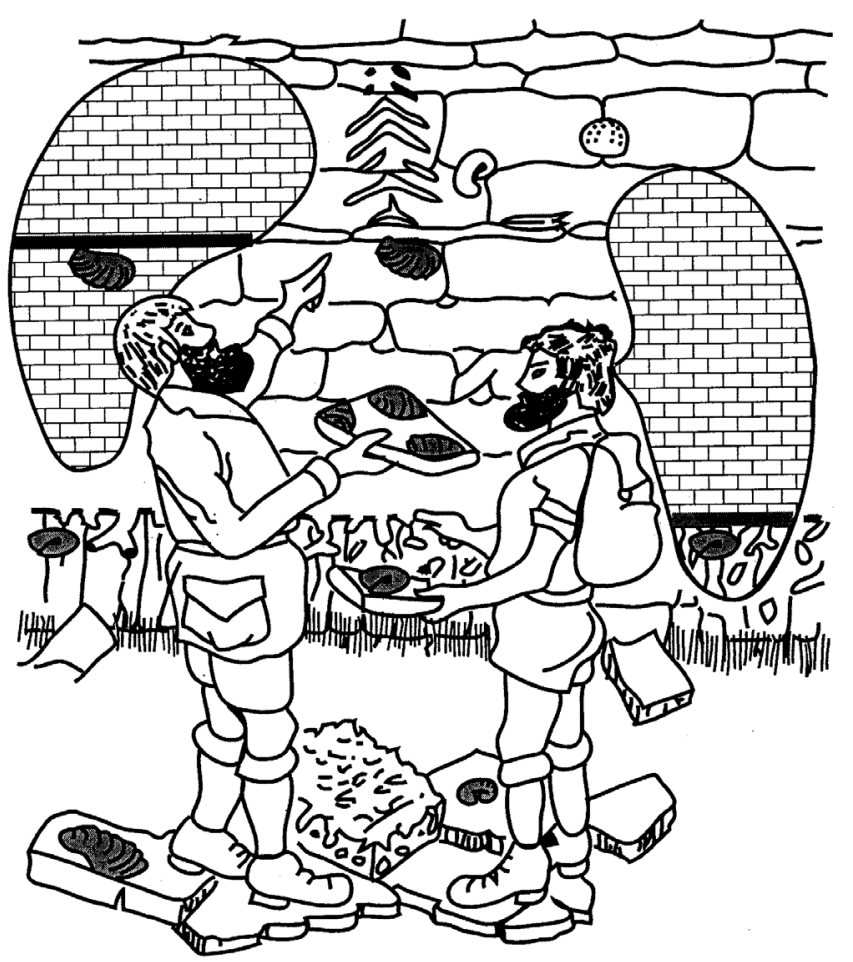

Different Concepts of Stage Boundaries

One reason that decisions on GSSP boundaries of international stages are difficult. Two experts with different paleontological specialties arguing over the suitable primary marker based on different biostratigraphic and lithologic criteria. Modified from Episodes, 1985, vol. 8, p. 89, figure 6 (based on a cartoon by Birkelund et al. and the Subcommission on Cretaceous Stratigraphy, 1983).

\section{Global Stratigraphic Framework}

Unification of regional chronostratigraphic nomenclature by organizing and documenting stratigraphic units in a global database; and the preparation and publication of global correlation charts. Even though the international geologic scale is defined with global events (when possible), there are numerous regional scales of traditional usage that are built from local significant changes in sediment, paleoenvironment or fossil characteristics. One must be able to easily convert from these traditional scales to the international standard, and to correlation among different regional scales. It is not only the nomenclature differences, but also the inter-calibration of high-resolution biostratigraphic zonations, sea-level excursions, and other aspects of the rock records. Indeed, this is the heart of compiling a global Earth history-how to relate the well-documented succes- 
sions of events in each region to the other regions of the planet. Only in this way can geoscientists understand the intricate workings of evolution, environmental cause-effect, tectonics and geochemical cycling. The compilation of these regional scales and high-resolution chronostratigraphic scales from around the globe must be an international effort. Examples of ICS work in this area include the "GeoWhen" database of regional stages (compiled by Robert Rohde and hosted on the ICS website), and the active promotion of on-line stratigraphic lexicons by the Stratigraphic Classification subcommission.

\section{Stratigraphic Guides}

Definition of principles of stratigraphic classification, terminology and procedure, and their publication in guides and glossaries. It is essential that global geologists use a global language and standardized terminology. The International Stratigraphic Guide provides such standards. The Guide is being updated, enhanced and clarified as stratigraphic concepts evolve, and ICS is striving to make the language of Earth history as logical and user-friendly as possible.

\section{Education, both for the public and for specialists}

Promotion of education in stratigraphic methods, dissemination of stratigraphic knowledge, evaluation of new stratigraphic methods, and integration of data and tools into a multidisciplinary stratigraphy. The Stratigraphic Information Services group under ICS is an ambitious effort to develop innovative teaching modules, on-line summaries of current and emerging stratigraphic concepts, and novel explorations using various tools to understand the stratigraphic record of our planet's complex and exciting history.

\section{Organization}

The range of activities of ICS are coordinated by an Executive Committee:

Chair: Felix Gradstein (Oslo, Norway; felix.gradstein @nhm.uio.no)

Vice-Chairs: Stan Finney (Long Beach, Calif., USA; scfinney @ csulb.edu) \& Rich Lane (National Sci. Foundation, USA; hlane@nsf.gov )

Secretary-General: James Ogg (West Lafayette, Indiana, USA; jogg@purdue.edu)

A second (and final) term will be served by Gradstein, Finney and Ogg during 2004-2008.

Most of ICS objectives are accomplished by a series of periodlevel subcommissions and task groups. In turn, each subcommission has task-oriented teams (for example, a short-term working group to formalize the Ladinian-Anisian boundary of the Triassic), and most subcommissions maintain their own websites. There are over 200 voting members among the subcommissions to make the formal decisions, but over 1000 stratigraphers are active within these subcommissions and working groups. The subcommissions with their 2004-2008 chairs and websites are:

\section{Quaternary}

Phil Gibbard (Cambridge, Great Britain;plg1@cus.cam.ac.uk) www.quaternary.stratigraphy.org.uk

\section{Neogene}

Frits Hilgen (Utrecht, Netherlands; fhilgen@geo.uu.nl)

www.geo.uu.nl/sns

\section{Paleogene}

Eustoquio Molina Martinez (Zaragoza, Spain; emolina @posta.unizar.es)

\section{Cretaceous}

Isabella Premoli Silva (Milan, Italy; Isabella.Premoli @unimi.it)
Jurassic

Nicol Morton (Vogüé, France; NICOL.MORTON @wanadoo.fr) Triassic

Michael Orchard (Vancouver, Canada; morchard @ nrcan.gc.ca) www.uni-muenster.de/GeoPalaeontologiel

Palaeo/Palbot/albomsl.htm

Permian

Charles Henderson (Calgary, Canada; cmhender @ucalgary.ca) pri.boisestate.edu/permophiles

Carboniferous

Philip Heckel (Iowa City, Iowa, USA; philip-heckel@uiowa.edu)

Devonian

Thomas Becker (Münster, Germany; rbecker @ uni-muenster.de) sds.uta.edu

\section{Silurian}

Rong Jiayu (Nanjing, China; jyrong @nigpas.ac.cn) iago.stfx.ca/people/mmelchin/SILURIAN9.HTM

Ordovician

Chen Xu (Nanjing, China; xu1936 @yahoo.com) seis.natsci.csulb.edu/ordstrat2/default.htm

\section{Cambrian}

Peng Shanchi (Nanjing, China; speng @ pub.jlonline.com) www.uni-wuerzburg.de/palaeontologie/ISCS/index.html

Ediacaran (Terminal Proterozoic) James Gehling (Adelaide, Australia; jgehling @ozemail.com.au)

Precambrian

Wouter Bleeker (Ottawa, Canada; Wbleeker @NRCan.gc.ca)

Stratigraphic Classification

Maria Bianca Cita (Milan, Italy; maria.cita @ unimi.it)

www.geocities.com/issc_arg

Stratigraphic Information Services

Eduardo A. M. Koutsoukos (Rio de Janeiro, Brazil; koutsoukos @ cenpes.petrobras.com.br), with Sorin Filipescu (ICS webmaster; Cluj-Napoca, Romania; sorin @bioge.ubbcluj.ro) www.stratigraphy.org

Prof. James Ogg

Dept. of Earth and Atmospheric Sciences

Purdue University

West Lafayette

Indiana 47907-1397

USA

E-mail:jogg@purdue.edu

Dr. Felix Gradstein

Museum for Geology and Paleontology

P.O. Box 1172 Blindern

$\mathrm{N}$-0316 Oslo

NORWAY

E-mail:felix.gradstein@nhm.uio.no 